\title{
Chemical Composition and Ruminal Degradability of Spineless Cactus Grown in Northeastern Brazil
}

\author{
Ângela M.V. Batista, ${ }^{1}$ Agenor C. Ribeironeto, ${ }^{2}$ Rodrigo B. Lucena, ${ }^{2}$ Djalma C. Santos, ${ }^{3}$ \\ Josè B. Dubeux, Jr., ${ }^{4}$ and Arif F. Mustafa ${ }^{5}$
}

Authors are ${ }^{1}$ Associate Professor, ${ }^{2}$ Research Assistants, and ${ }^{4}$ Assistant Professor, Departmento de Zootecnia, Universidade Federal Rural de Pernambuco, Av. Dom Manoel de Medeiros, S/N, Dois Irmãos, 52171-900 Recife, PE, Brazil; ${ }^{3}$ Research Scientist, Empresa Pernambucana de Pesquisa Agropecuária (IPA), Av. Gal. San Martin, Bonji, 50761-000 Recife, Brazil; and ${ }^{5}$ Associate Professor, Department of Animal Science, McGill University, 21111 Lakeshore Rd, Ste-Anne-De-Bellevue, QC H9X 3V9, Canada.

\begin{abstract}
A study was conducted to determine chemical composition and ruminal nutrient degradability of eight spineless cactus cultivars grown in northeastern Brazil. Results showed that neutral detergent fiber was similar for all cultivars and averaged $249 \mathrm{~g} \cdot \mathrm{kg}^{-1} \pm 7.3$ SEM. Acid detergent fiber ranged between $148 \mathrm{~g} \cdot \mathrm{kg}^{-1}$ and $207 \mathrm{~g} \cdot \mathrm{kg}^{-1}$ with some significant differences between cultivars. Starch and water-soluble carbohydrates were similar for all cultivars and averaged $198 \mathrm{~g} \cdot \mathrm{kg}^{-1} \pm 6.3$ SEM and $155 \mathrm{~g} \cdot \mathrm{kg}^{-1} \pm 9.0 \mathrm{SEM}$, respectively. Protein content was less than $50 \mathrm{~g} \cdot \mathrm{kg}^{-1}$ with some significant differences between cultivars. Calcium was the mineral with the highest concentration followed by potassium and magnesium with no differences between cultivars. Effective ruminal degradability of dry matter and neutral detergent fiber were unaffected by cultivar and averaged $701 \mathrm{~g} \cdot \mathrm{kg}^{-1} \pm 8.4 \mathrm{SEM}$ and $503 \mathrm{~g} \cdot \mathrm{kg}^{-1} \pm 5.8 \mathrm{SEM}$, respectively. It was concluded that cultivars had little impact on chemical composition and ruminal degradability of spineless cactus. Based on chemical composition and in situ ruminal degradability, spineless cactus can be considered an excellent source of fermentable carbohydrates for grazing and nongrazing ruminants. Because of its high carbohydrate quality, spineless cactus can be used an emergency feed or as part of a complete diet providing that the diet contains an adequate amount of degradable protein.
\end{abstract}

\section{Resumen}

Se llevó a cabo un estudio para determinar la composición química y la degradación de nutrientes a nivel ruminal de ocho especies de cactus sin espinas producidas en el Noreste de Brazil. Los resultados demuestran que la fibra neutro detergente fue similar para todas la variedades con un promedio de $249 \pm 7.3 \mathrm{~g} \cdot \mathrm{kg}^{-1}$. La fibra ácido detergente presentó un rango de 148 a $207 \mathrm{~g} \cdot \mathrm{kg}^{-1}$ con algunas diferencias significativas entre especies. El almidón y los carbohidratos solubles en agua fueron también similares para todas las variedades con un promedio de $198 \pm 6.3$ y $155 \pm 9.0 \mathrm{~g} \cdot \mathrm{kg}^{-1}$, respectivamente. El contenido de proteína fue menor que $50 \mathrm{~g} \cdot \mathrm{kg}^{-1}$ con algunas diferencias significativas entre variedades. Calcio fue el mineral con las concentraciones más altas seguidas por $\mathrm{K}$ y Mg sin encontrar diferencias entre especies. La degradación ruminal efectiva tanto de la materia seca como de la fibra neutra detergente no fueron afectados por las especies y tuvieron un promedio de $701 \pm 8.4 \mathrm{y}$ $503 \pm 5.8 \mathrm{~g} \cdot \mathrm{kg}^{-1}$, respectivamente. Se puede concluir que las especies tienen poco impacto en la composición química y la degradación ruminal de los cactus sin espinas. Basándose en la composición química y la degradabilidad ruminal in situ, los cactus sin espinas pueden considerarse como una fuente excelente de carbohidratos fermentables para rumiantes tanto en pastoreo como en no-pastoreo. Debido a la alta calidad de carbohidratos los cactus sin espinas pueden utilizarse como un alimento de emergencia o como parte de una dieta completa cuando esa dieta contiene una cantidad adecuada de proteína degradable.

Key Words: cultivar

\section{INTRODUCTION}

Forage cacti consist of several species of the genera Opuntia and Nopalea, which belong to the Cactaceae family (Santos and Albuquerque 2002). Cactus is an important forage in several arid and semiarid regions in the world because of its high productivity under harsh environments (Ben Salem et al.

Correspondence: Dr Arif F. Mustafa, Dept of Animal Science, McGill University, 21111 Lakeshore Rd, Ste-Anne-De-Bellevue, QC H9X 3V9, Canada. Email: arif.mustafa@mcgill.ca

Manuscript received 11 September 2007; manuscript accepted 9 January 2009. 2002a). Benefits of cactus include high biomass yield, drought resistance, salinity tolerance, and soil adaptability (Nobel 2002). There are more than 500000 ha under cactus cultivation in the northeastern region of Brazil where large quantities are fed during the dry season to ruminants because of the lack of other forages (Santos and Albuquerque 2002). Cactus is also fed to dairy cows as an ingredient in complete diets throughout the year (Santos and Albuquerque 2002). Several factors can affect chemical composition and therefore nutritive value of cactus. These include type of cultivar and species, stage of maturity, soil moisture and nutrient composition, fertilization, 
and agronomical practices such as population density (Dubeux et al. 2006). Criteria for breeding programs of forage cactus include high yield, insect tolerance, and adaptability to local conditions. New high yielding and insect (Dactylopius coccus)resistant cultivars have recently been propagated by Empresa Pernambucana de Pesquisa Agropecuária (IPA) in Pernambuco, Brazil. Despite the fact that cactus is a common ruminant feed in several regions of the world, comparative data on its chemical composition and ruminal degradability of different cultivars of cactus are limited. The objective of this study was to determine effects of cultivar on chemical composition and ruminal dry matter (DM) and neutral detergent fiber (NDF) degradability of spineless cactus cladodes grown in the northeastern region of Brazil.

\section{METHODS}

Eight cactus cultivars were grown in Arcoverde, in the semiarid region of Pernambuco state, northeast of Brazil in 1998 as a part of a cactus-breeding program. Each cultivar was planted in three plots $(1.0 \times 0.5 \mathrm{~m}$ each $)$ as a randomized complete block design (i.e., eight cultivars within each block, $n=24$ ). Plants were harvested every $2 \mathrm{yr}$ and $20000 \mathrm{~kg} \cdot \mathrm{ha}^{-1}$ of manure were applied after each harvest. Cultivars included the two most commonly grown cultivars in northeastern Brazil (Gigante and Miúda), two insect (Dactylopius coccus)-resistant cultivars (1317 Chile and 1267 Algeria), and four high-producing cultivars (i.e. IPA-20, IPA-90-92, IPA-90-155, and Additional 1258). All cultivars belonged to the genus Opuntia except for Miúda, which belonged to the genus Nopalea. In 2007, plants were manually harvested when they were 2 yr old (early flowering stage) by cutting cladodes at the base using a sharp knife. Three plants per plot were harvested and composited as one replicate.

Following harvest, cladodes were cut horizontally into two halves, which were further cut into small pieces and dried in a forced-air oven at $55^{\circ} \mathrm{C}$ for $72 \mathrm{~h}$. Dried samples were ground through a $2-\mathrm{mm}$ screen and subsamples (100 g) were reground through a 1-mm screen. Ground samples (1-mm screen) were then analyzed for DM, ash, ether extract, crude protein (CP, Kjeldahl $N \times 6.25)$, and acid detergent lignin according to the procedures of the Association Of Official Analytical Chemists (AOAC 1990). NDF (Van Soest et al. 1991) and acid detergent fiber (ADF; AOAC 1990) were determined using an Ankom fiber analyzer (Ankom Technology Corporation, Macedon, NY). Neutral and acid detergent insoluble proteins were determined by analyzing NDF and ADF residues, respectively, for total nitrogen. Starch was determined according to the procedure of McCleary et al. (1997) and water-soluble carbohydrates (WSC) according to Dubois et al. (1956).

Mineral concentrations were determined following digestion with a perchloric-nitric acid mixture (AOAC 1990, method 968.08) using a Perkin-Elmer Model 500 atomic absorption spectrophotometer (Perkin-Elmer, Norwalk, CT). Phosphorus concentration was determined colorimetrically (Pharmacia LKB Ultraspec III, Cambridge, United Kingdom). Oxalate concentration was determined using an enzymatic kit (Trinity Biotech, Newark, NJ) as described by Horner et al. (2005). All values for chemical composition were expressed on DM basis.
Three mature bucks fitted with ruminal cannulae and fed chopped tifton hay ad libitum were used for in situ ruminal incubations. Equal portions (200 g) from the three replicates of each cultivar were composited to obtain a single sample for each cultivar. Duplicate samples weighing approximately $4 \mathrm{~g}$ (air basis) were placed into nylon bags $(10 \times 8 \mathrm{~cm}$; average pore size, $50 \mu \mathrm{m}$ ) and incubated in the rumens of the three bucks for 2, 4, 8, 12, 24, 48, and $72 \mathrm{~h}$ (two bags per cultivar per incubation time per animal).

Following incubations, bags were washed in tap water until the water was clear and washed bags were then dried at $60^{\circ} \mathrm{C}$ for $72 \mathrm{~h}$. The 0 -h wash-out was determined by washing duplicate bags containing samples of the eight cactus cultivars. Residues from the nylon bags at each incubation time were analyzed for DM and NDF as described previously. The disappearance at each incubation time was calculated from the concentrations of DM and NDF in the original samples and the residues were used to estimate $\mathrm{DM}, \mathrm{CP}$, and NDF degradation parameters using the equation of Dhanoa (1989):

$$
p=a+b\left(1-e^{-c(t-L)}\right)
$$

where $p$ is ruminal disappearance at time $t\left(\mathrm{~g} \cdot \mathrm{kg}^{-1}\right), a$ the soluble fraction $\left(\mathrm{g} \cdot \mathrm{kg}^{-1}\right), b$ is the slowly degradable fraction $\left(\mathrm{g} \cdot \mathrm{kg}^{-1}\right), c$ is the rate at which the $b$ fraction is degraded $\left(\% \cdot \mathrm{h}^{-1}\right)$, and $L$ is a discrete lag phase (h). The constants $a, b$, and $c$ were estimated using an iterative nonlinear regression procedure of SAS (1989). Effective ruminal degradabilities of DM and NDF were estimated at rumen outflow rate of $0.05 \cdot \mathrm{h}^{-1}$ using the equation of Ørskov and McDonald (1979).

All data were analyzed using PROC GLM of SAS (SAS 1989). Data for chemical composition were analyzed as a randomized complete block design (eight treatments and three blocks) whereas data of the in situ study were analyzed as a randomized complete block design using animals as blocks. Treatment differences were declared significant when $P<0.05$.

\section{RESULTS}

Chemical composition of the cactus cultivars is shown in Table 1. DM content was higher $(P<0.05)$ for Miúda than for Giganti, APA-20, Additional 1258, Algeria, and Chile cultivars. Ash content ranged between $68 \mathrm{~g} \cdot \mathrm{kg}^{-1}$ and $94 \mathrm{~g} \cdot \mathrm{kg}^{-1}$ with the largest differences observed between Algeria and IPA90-155 cultivars. Ether extract was low and similar for all cultivars. NDF was not influenced by cultivar and averaged $249 \mathrm{~g} \cdot \mathrm{kg}^{-1}$. ADF was higher $(P<0.05)$ for IPA-90-155 than for Additional 1258, Chile, and Miúda and was higher $(P<0.05)$ for Algeria, IPA-90-92, IPA-20, and Giganti than for Miúda. However, sequential ADF was only lower $(P<0.05)$ for Miúda than for the other cultivars. Acid detergent lignin was low for all cultivars and was higher $(P<0.05)$ for IPA-90-155 than for Additional 1258, Algeria, and Chile cultivars. Starch and WSC concentrations were not influenced by cultivar and averaged $198 \mathrm{~g} \cdot \mathrm{kg}^{-1}$ and $155 \mathrm{~g} \cdot \mathrm{kg}^{-1}$, respectively. Total carbohydrates constituted 
Table 1. Effect of cultivar on chemical composition of spineless cactus cladodes (dry-matter basis). Means in the same row with different letters are different $(P<0.05)$.

\begin{tabular}{|c|c|c|c|c|c|c|c|c|c|}
\hline & \multicolumn{9}{|c|}{ Cactus cultivar } \\
\hline & Gigante & Miúda & IPA-20 & IPA-90-92 & IPA-90-155 & Additional 1258 & Algeria & Chile & SEM \\
\hline Dry matter $\left(\mathrm{g} \cdot \mathrm{kg}^{-1}\right)$ & $153 \mathrm{bc}$ & $187 \mathrm{a}$ & 156 bc & $165 a b$ & $170 \mathrm{ab}$ & 148 bc & $126 \mathrm{c}$ & $138 \mathrm{bc}$ & 7.1 \\
\hline Ash $\left(\mathrm{g} \cdot \mathrm{kg}^{-1}\right)$ & $81 \mathrm{~b}$ & $81 \mathrm{~b}$ & 72 bc & $78 \mathrm{bc}$ & $68 c$ & 76 bc & $94 \mathrm{a}$ & 79 bc & 2.6 \\
\hline Ether extract $\left(\mathrm{g} \cdot \mathrm{kg}^{-1}\right)$ & 24 & 20 & 20 & 23 & 23 & 19 & 17 & 23 & 1.9 \\
\hline Neutral detergent fiber $\left(\mathrm{g} \cdot \mathrm{kg}^{-1}\right)$ & 248 & 241 & 247 & 255 & 263 & 241 & 246 & 249 & 6.3 \\
\hline Acid detergent fiber $\left(\mathrm{g} \cdot \mathrm{kg}^{-1}\right)$ & $179 a b$ & $148 \mathrm{c}$ & $185 a b$ & $178 \mathrm{ab}$ & $207 \mathrm{a}$ & 162 bc & $183 a b$ & $158 \mathrm{bc}$ & 7.1 \\
\hline $\operatorname{Lignin}\left(\mathrm{g} \cdot \mathrm{kg}^{-1}\right)$ & $13 a b$ & $13 a b$ & $12 a b$ & $13 a b$ & $17 \mathrm{a}$ & $7 \mathrm{~b}$ & $10 \mathrm{~b}$ & $8 \mathrm{~b}$ & 1.4 \\
\hline Starch $\left(g \cdot \mathrm{kg}^{-1}\right)$ & 207 & 205 & 198 & 194 & 204 & 190 & 193 & 195 & 14.2 \\
\hline Water-soluble carbohydrates $\left(\mathrm{g} \cdot \mathrm{kg}^{-1}\right)$ & 154 & 146 & 166 & 150 & 153 & 161 & 141 & 165 & 12.2 \\
\hline Total carbohydrates $\left(\mathrm{g} \cdot \mathrm{kg}^{-1}\right)$ & $625 \mathrm{~b}$ & $660 a b$ & $690 \mathrm{a}$ & $690 \mathrm{a}$ & $711 \mathrm{a}$ & $666 a b$ & $617 \mathrm{~b}$ & $633 \mathrm{~b}$ & 14.0 \\
\hline Nonstructural carbohydrates $\left(\mathrm{g} \cdot \mathrm{kg}^{-1}\right)$ & 398 bc & $439 a b c$ & $464 \mathrm{ab}$ & $462 \mathrm{ab}$ & 468 a & $445 a b c$ & $381 \mathrm{c}$ & $404 a b c$ & 15.0 \\
\hline$C P^{1}\left(g \cdot \mathrm{kg}^{-1}\right)$ & $44 \mathrm{a}$ & $33 \mathrm{~b}$ & $37 \mathrm{~b}$ & $34 \mathrm{~b}$ & $37 \mathrm{~b}$ & $36 \mathrm{~b}$ & $44 \mathrm{a}$ & $39 \mathrm{~b}$ & 1.3 \\
\hline $\mathrm{NDICP}^{1}\left(\mathrm{~g} \cdot \mathrm{kg}^{-1}\right.$ of $\left.\mathrm{CP}\right)$ & 195 & 208 & 218 & 234 & 241 & 248 & 213 & 228 & 10.4 \\
\hline $\operatorname{ADICP}^{1}\left(\mathrm{~g} \cdot \mathrm{kg}^{-1}\right.$ of CP $)$ & 82 & 81 & 95 & 100 & 93 & 80 & 89 & 75 & 7.4 \\
\hline $\mathrm{Ca}\left(\mathrm{mg} \cdot \mathrm{kg}^{-1}\right)$ & 18.73 & 21.41 & 16.76 & 17.26 & 17.57 & 21.31 & 23.11 & 20.67 & 1.36 \\
\hline $\mathrm{P}\left(\mathrm{mg} \cdot \mathrm{kg}^{-1}\right)$ & 1.25 & 1.02 & 1.14 & 1.44 & 1.02 & 1.24 & 1.18 & 1.05 & 0.124 \\
\hline $\mathrm{Mg}\left(\mathrm{mg} \cdot \mathrm{kg}^{-1}\right)$ & 8.88 & 10.13 & 9.21 & 7.91 & 9.01 & 9.40 & 9.90 & 10.72 & 0.740 \\
\hline $\mathrm{K}\left(\mathrm{mg} \cdot \mathrm{kg}^{-1}\right)$ & 8.52 & 8.64 & 8.00 & 8.10 & 7.56 & 10.33 & 8.49 & 7.82 & 1.20 \\
\hline $\mathrm{Na}\left(\mathrm{mg} \cdot \mathrm{kg}^{-1}\right)$ & 0.05 & 0.06 & 0.03 & 0.05 & 0.06 & 0.01 & 0.01 & 0.01 & 0.021 \\
\hline $\mathrm{Zn}\left(\mathrm{mg} \cdot \mathrm{kg}^{-1}\right)$ & 0.04 & 0.02 & 0.04 & 0.03 & 0.08 & 0.03 & 0.05 & 0.08 & 0.016 \\
\hline Oxalate $\left(\mathrm{mg} \cdot \mathrm{kg}^{-1}\right)$ & 1.23 & 1.95 & 2.10 & 1.30 & 1.60 & 1.90 & 1.50 & 1.90 & 0.298 \\
\hline
\end{tabular}

${ }^{1} \mathrm{CP}$ indicates crude protein; NDICP, neutral detergent insoluble protein; ADICP, acid detergent insoluble protein.

more than $60 \%$ of the DM and were higher $(P<0.05)$ for the IPA cultivars than for Giganti and Algeria cultivars. Nonstructural carbohydrates made up more than $50 \%$ of the total carbohydrates and were higher $(P<0.05)$ for IPA-90-155 than for Algeria and Gigante cultivars.

$\mathrm{CP}$ content of all cultivars was less than $50 \mathrm{~g} \cdot \mathrm{kg}^{-1}$ and was higher $(P<0.05)$ for Giganti and Algeria than for the other cultivars (Table 1). Neutral and acid detergent insoluble protein concentrations were similar for all cultivars and averaged $223 \mathrm{~g} \cdot \mathrm{kg}^{-1}$ and $87 \mathrm{~g} \cdot \mathrm{kg}^{-1}$ of $\mathrm{CP}$, respectively. Cultivar had no effect on mineral composition of cactus (Table 1). Calcium was the mineral in the highest concentration in all cultivars followed by $\mathrm{Mg}$ and $\mathrm{K}$. Oxalate concentration was also not influenced by cultivar and averaged $1.69 \mathrm{~g} \cdot \mathrm{kg}^{-1}$.

In situ soluble DM fraction ranged between $269 \mathrm{~g} \cdot \mathrm{kg}^{-1}$ and $331 \mathrm{~g} \cdot \mathrm{kg}^{-1}$ of DM and was higher $(P<0.05)$ for Gigante than for IPA-20, IPA-90-92, and Chile cultivars. Rate of degradation of the slowly degradable DM fraction was higher $(P<0.05)$ for Chile than for the other cultivars (Table 2). However, effective ruminal degradability of DM was similar for all cultivars and averaged $701 \mathrm{~g} \cdot \mathrm{kg}^{-1}$.

Differences in NDF kinetic parameters between cactus cultivars were small (Table 2). In situ soluble NDF fraction was smaller $(P<0.05)$ for Algeria than for the Gigante cultivar whereas rate of degradation of slowly degradable NDF fraction was greater $(P<0.05)$ for Miúda than for the other cultivars. However, slowly degradable NDF fraction and ruminal effective degradability of NDF were not influenced by cultivar and averaged $697 \mathrm{~g} \cdot \mathrm{kg}^{-1}$ and $503 \mathrm{~g} \cdot \mathrm{kg}^{-1}$, respectively.

\section{DISCUSSION}

Values of ash and mineral concentrations in the present study were lower than those reported for spineless cactus cultivars from other locations in northeastern Brazil (Batista et al. 2003a, 2003b) and Tunisia (Ben Salem et al. 1996). Ben Thlija (1987) indicated that ash content of spineless cactus could be as high as $300 \mathrm{~g} \cdot \mathrm{kg}^{-1} \mathrm{DM}$. Factors such as soil mineral and moisture contents can significantly affect ash and mineral concentrations of spineless cactus. Water deficiency and high levels of $\mathrm{Ca}$ compounds in the soil tend to push cacti to accumulate $\mathrm{Ca}$ in their cladodes (Nobel 2002). The low Ca concentrations for the cactus cultivars in our study were reflected in the oxalate content, which was lower than the value reported by Ben Salem et al. $\left(2002 \mathrm{~b} ; 131 \mathrm{~g} \cdot \mathrm{kg}^{-1}\right)$. Oxalate synthesis is considered a means of reducing the negative impact of excessive Ca uptake by cactus (Libert and Franceschi 1987).

Our NDF, ADF, and lignin values were in good agreement with those reported by Batista et al. (2003a). NDF values for spineless cactus ranged between $186 \mathrm{~g} \cdot \mathrm{kg}^{-1}$ and $392 \mathrm{~g} \cdot \mathrm{kg}^{-1}$ whereas ADF concentration ranged from $113 \mathrm{~g} \cdot \mathrm{kg}^{-1}$ to $248 \mathrm{~g} \cdot \mathrm{kg}^{-1}$ (Ben Thlija 1987; Ben Salem et al. 1996; Batista et al. 2003a, 2003b; Gebremariam et al. 2006). Variations in fiber values between studies can be due to differences in cactus species and cultivar and stage of maturity. Values of NDF and ADF may also vary according to the method of analysis used due to the high ash, pectin, and nonstructural carbohydrate contents of cactus. Fiber analysis revealed more differences in ADF than in NDF between the cactus cultivars, which is in agreement with our previous findings (Batista et al. 2003a). Ben 
Table 2. Effects of cultivar on ruminal dry matter (DM) and neutral detergent fiber (NDF) degradability of spineless cactus cladodes. Means in the same row with different letters are different $(P<0.05)$.

\begin{tabular}{|c|c|c|c|c|c|c|c|c|c|}
\hline & \multicolumn{9}{|c|}{ Cactus cultivar } \\
\hline & Gigante & Miúda & IPA-20 & IPA-90-92 & IPA-90-155 & Additional 1258 & Algeria & Chile & SEM \\
\hline \multicolumn{10}{|l|}{$\overline{D M}$} \\
\hline Slowly degradable fraction $\left(\mathrm{g} \cdot \mathrm{kg}^{-1}\right.$ of $\left.\mathrm{DM}\right)$ & $560 \mathrm{~b}$ & $573 \mathrm{~b}$ & $582 \mathrm{~b}$ & $575 \mathrm{~b}$ & $563 \mathrm{~b}$ & $578 \mathrm{~b}$ & $568 \mathrm{~b}$ & $627 \mathrm{a}$ & 5.1 \\
\hline Degradation rate $\left(\% \cdot \mathrm{h}^{-1}\right)$ & $10.7 \mathrm{~b}$ & $10.9 \mathrm{~b}$ & $11.1 \mathrm{~b}$ & $10.5 \mathrm{~b}$ & $10.8 \mathrm{~b}$ & $10.1 \mathrm{~b}$ & $10.0 \mathrm{~b}$ & $12.3 \mathrm{a}$ & 0.25 \\
\hline Lag time (h) & 0.2 & 0.2 & 0.1 & 0.1 & 0.1 & 0.2 & 0.1 & 0.1 & 0.04 \\
\hline \multicolumn{10}{|l|}{ NDF } \\
\hline Soluble fraction $\left(\mathrm{g} \cdot \mathrm{kg}^{-1}\right.$ of NDF) & $109 \mathrm{a}$ & $99 a b$ & $101 \mathrm{ab}$ & $105 a b$ & $106 a b$ & $99 a b$ & $98 \mathrm{~b}$ & $107 \mathrm{ab}$ & 2.5 \\
\hline Slowly degradable fraction $\left(\mathrm{g} \cdot \mathrm{kg}^{-1}\right.$ of NDF) & 704 & 690 & 693 & 705 & 701 & 692 & 700 & 694 & 4.9 \\
\hline Degradation rate $\left(\% \cdot \mathrm{h}^{-1}\right)$ & $6.5 \mathrm{~b}$ & $7.6 \mathrm{a}$ & $7.0 \mathrm{~b}$ & $6.7 \mathrm{~b}$ & $6.5 \mathrm{~b}$ & $6.7 \mathrm{~b}$ & $6.7 \mathrm{~b}$ & $6.4 \mathrm{~b}$ & 0.18 \\
\hline Lag time (h) & 0.1 & 0.3 & 0.2 & 0.2 & 0.2 & 0.2 & 0.1 & 0.1 & 0.08 \\
\hline
\end{tabular}

Thlija (1987) also reported more variations in NDF than in ADF contents of five Opuntia species. Because of its high nonstructural carbohydrate and low lignin concentrations, spineless cactus can be considered a good source of fermentable carbohydrates for ruminants. The digestible energy content of cactus is $7 \%$ higher than that of early bloom alfalfa hay (National Research Council 2007).

All cactus cultivars contained moderate levels of starch, which were higher than the values reported by Batista et al. (2003a) but within the range reported by Retamal et al. (1987; $\left.77-226 \mathrm{~g} \cdot \mathrm{kg}^{-1}\right)$. Retamal et al. (1987) found that starch content of cactus varies according to stage of maturity with young cladodes containing more starch than mature ones. Cactus can be considered unique forage because of its moderate starch and WSC concentrations. Batista et al. (2003a) reported that rapidly (i.e., sugars and organic acids) and intermediately (i.e., starch) degradable carbohydrate fractions constituted $42 \%$ and $19 \%$, respectively, of the total carbohydrates in cactus.

Cactus is characterized by a low CP concentration. Average values of $38 \mathrm{~g} \cdot \mathrm{kg}^{-1}$ and $58 \mathrm{~g} \cdot \mathrm{kg}^{-1}$ have been reported by Ben Salem et al. (1994) and Ben Salem et al. (1996), respectively. However, Batista et al. (2003a, 2003b) reported higher CP values $\left(60-77 \mathrm{~g} \cdot \mathrm{kg}^{-1}\right)$ for several cactus cultivars from northeastern Brazil. CP content of cactus is affected by factors such as soil moisture and $\mathrm{N}$ contents and $\mathrm{N}$ fertilization (Nefzaoui and Ben Salem 2002; Dubeux et al. 2006). Because of low CP content, $\mathrm{N}$ supplementation improved performance of animals fed diets containing cactus (Ben Salem et al. 2002a; Misra et al. 2006).

All cactus cultivars had high ruminal DM degradability with little differences between cultivars (Table 2). In agreement with our results, Ben Salem et al. (2002a) and Batista et al. (2003b) reported in situ DM disappearance of $760 \mathrm{~g} \cdot \mathrm{kg}^{-1}$ to $800 \mathrm{~g} \cdot \mathrm{kg}^{-1}$ for spineless cactus following $48 \mathrm{~h}$ of ruminal incubation. High ruminal DM degradability of cacti is likely due to their high nonstructural carbohydrate and low lignin contents, which may explain the high degradation rate of the slowly degradable DM fraction. High degradation rates (7.0-
$10.0 \% \cdot \mathrm{h}^{-1}$ ) of potentially degradable DM for different cactus cultivars have also been reported by Batista et al. (2003b). Because of its high ruminal degradability, feeding high levels of cactus may result in digestive disturbances such as bloat and diarrhea (Gebremariam 2006). However, feeding nonbloat forage such as bermudagrass hay can reduce the incidence of digestive disturbances when high levels of cactus are fed (Vieira et al. 2008).

Values of in situ soluble DM fraction in our study were higher whereas values of potentially degradable DM fraction were lower than those reported for 10 cultivars of spineless cacti (Batista et al. 2003b). These discrepancies are likely because of differences in materials used in the in situ incubations. Whereas dry ground samples were used in our study, Batista et al. (2003b) used fresh cacti cut into small pieces. Data for ruminal degradability of cactus fiber are limited. Batista et al. (2003a) reported that $63 \%$ of NDF of three cactus cultivars disappeared following $48 \mathrm{~h}$ of in situ ruminal incubation. High rate of degradation on NDF can be attributed to low lignin concentration.

\section{MANAGEMENT IMPLICATIONS}

Our results showed that cultivar had minimal effects on chemical composition and ruminal degradability of cactus. Because of its low fiber and moderate starch and WSC concentrations, cactus can be considered a good source of readily fermentable nonfiber carbohydrates. The cell wall fraction is also expected to be highly degradable in the rumen because of its low lignin content. Feeding programs containing cactus should focus on adequate supplementation with protein and effective fiber sources.

\section{LITERATURE CITED}

[AOAC] Association Of Official Analytical Chemists. 1999. Official methods of analysis. 15th ed. Arlington, VA, USA: Association Of Official Analytical Chemists. 2000 p. 
Batista, A. M. V., A. F. Mustafa, T. McAllister, Y. Wang, H. Solta, and J. J. McKinnon. 2003a. Effects of variety on chemical composition, in situ nutrient disappearance and in vitro gas production of spineless cacti. Journal of the Science of Food and Agriculture 83:440-445.

Batista, A. M. V., A. F. Mustafa, G. R. A. Santos, F. F. R. De Carvalho, J. C. B. Dubeux, JR., M. A. LIRA, AND S. B. P. Barbosa. 2003b. Chemical composition and ruminal dry matter and crude protein degradability of spineless cactus. Journal of Agronomy and Crop Science 189:123-126.

Ben Salem, H., A. Nefzaoul, and H. Abdouli. 1994. Palatability of shrubs and fodder trees measured on sheep and dromedaries: methodological approach. Animal Feed Science and Technology 46:143-153.

Ben Salem, H., A. Nefzaoui, H. Abdouli, and E. R. Ørskov. 1996. Effect of increasing level of spineless cactus (Opuntia ficus-indica var. inermis) on intake and digestion by sheep given straw-based diets. Animal Science 62:293-299.

Ben Salem, H., A. Nefzadui, and L. Ben Salem. 2002a. Supplementing spineless cactus (Opuntia ficus indica f. inermis) based diets with urea treated straw or oldman saltbush (Atriplex nummularia L). Effects on intake, digestion and sheep growth. Journal of Agricultural Science 138:85-92.

Ben Salem, H., A. Nefzadui, and L. Ben Salem. 2002b. Supplementation of Acacia cyanophylla Lindl. foliage based diets with barley or shrubs from arid areas (Opuntia ficus indica f. inermis and Atriplex nummularia $L$ ) on digestibility and growth in sheep. Animal Feed Science and Technology 96:15-30.

Ben ThliJA, A. 1987. Nutritional value of several Opuntia species [thesis]. Corvallis, OR, USA: Oregon State University. $84 \mathrm{p}$.

DhanoA, M. S. 1988. On the analysis of dacron bag data for low digestibility feed. Grass Forage Science 43:441-444.

Dubeux, J. C., M. V. Ferreira Dos Santos, M. Andrade Lira, D. Cordeiro Dos Santos, I. Farias, L. E. Lima, and R. L. C. Ferreira. 2006. Productivity of Opuntia ficusindica (L.) Miller under different $\mathrm{N}$ and $\mathrm{P}$ fertilization and plant population in north-east Brazil. Journal of Arid Environments 67:357-372.

Dubols, M., K. A. Giles, J. K. Hamilton, P. A. Robers, and F. Smith. 1956. Colorimetric method for determination of sugars and related substances. Analytical Chemistry 28:350-356.

Gebremariam, T., S. Melaku, and A. Yami. 2006. Effect of different levels of cactus (Opuntia ficus-indica) inclusion on feed intake, digestibility and body weight gain in tef (Ergagrostis tef) straw-based feeding of sheep. Animal Feed Science and Technology 131:41-52.
Horner, H. T., T. Cervantes-Martinez, R. Healy, M. B. Reddy, B. L. Deardorff, T. B. Balley, I. Al-Wahsh, L. K. Massey, and R. G. Palmer. 2005. Oxalate and phytate concentrations in seeds of soybean cultivars [Glycine max (L.) Merr.]. Journal of Agriculture and Food Chemistry 53:7870-7877.

Libert, B., AND V. R. FrancesCHI. 1987. Oxalate in crop plants. Journal of Agriculture and Food Chemistry 35:926-938.

McCleary, B. V., C. C. Gibson, and C. C. Mugford. 1997. Measurements of total starch in cereal products by amyloglucosidase- $\alpha$-amylase method. Collaborative study. Journal of the Association of Official Analytical Chemists International 77:81-86.

National Research Council. 2007. Nutrient requirements of small ruminants. Washington, DC, USA: National Academies Press. 362 p.

Nefzaoui, A., and H. Ben Salem. 2002. Opuntia spp.-a strategic fodder and efficient tool to combact desertification in the Wana region. Rome, Italy: FAO Plant Protection and Production Paper 169. p. 73-89.

NobeL, P. S. 2002. Ecophysiology of Opuntia ficus-indica. In: C. MondragónJacobo and S. Pérez-González [eds.]. Cactus (Optunia spp.) as forage. FAO Plant Protection and Production Paper 169, Rome, Italy. p. 13-20.

Ørskov, E. R., AND I. McDonald. 1979. The estimation of protein degradability in the rumen from incubation measurements weighed according to rate of passage. The Journal of Agricultural Science (Camb.) 92:499-503.

Retamal, N., J. M. Duran, and J. Fernandez. 1987. Seasonal variations of chemical composition in prickly pear (Opuntia-ficus-indica (L) Miller). Journal of the Science of Food Agriculture 38:303-311.

Santos, D. C., and S. G. Albuquerque. 2002. Opuntia as fodder in the semi-arid northeast Brazil. In: C. Mondragón-Jacobo and S. Pérez-González [EDS.]. Cactus (Optunia spp.) as forage. Rome, Italy: FAO Plant Protection and Production Paper 169. p. 37-50.

SAS. 1989. SAS User's Guide. Cary, NC, USA: SAS Institute, Inc. 1686 p.

Van Soest, P. J., P. J. Robertson, and B. A. Lewis. 1991. Methods for dietary fiber, neutral detergent fiber, and nonstarch polysaccharides in relation to animal nutrition. Journal of Dairy Science 74:3583-3597.

Vieira, E. L., A. M. Batista, A. Guim, F. F. Carvalho, A. C. Nascimento, R. F. S. Araújo, And A. F. Mustafa. 2008. Effects of hay inclusion on intake in vivo nutrient utilization and ruminal fermentation of goats fed spineless cactus (Opuntia fícus-indica Mill) based diets. Animal Feed Science and Technology 141:199208. 